\section{Assessment of staff ICT literacy competence in Nigerian federal university libraries}

\section{David Oguche}

Nigerian Institute of Advanced Legal Studies, Abuja
Information Impact:

Journal of Information and Knowledge Management 2017, Vol. 8 (2) Pg 77 - 89 ISSN: $2141-4297$ (print) ISSN: 2360 - 994X (e-version) www.informationimpact.org

\begin{abstract}
This paper discussed information communication technology (ICT) literacy as the relative measure of library staff's capacity to make appropriate use of ICTs for information acquisition, organization, retrieval and dissemination. It also examined the impact of Information and Communication Technology (ICT) literacy on the duties of library staff in selected federal university libraries in Nigeria. The research employs a purposive sampling technique to select six federal universities one each from the six geopolitical zones in Nigeria. Questionnaire was used for data collection which yielded a $79.7 \%$ response rate. A major finding of the study revealed that over $60 \%$ of the respondents were competent in sending emails, use of search engines, the use of Microsoft application software such as Ms Word and Ms Power Point. The study concluded that the level of ICT literacy competence among the library staff in the Nigerian federal university libraries studied is on the average
\end{abstract}

Keywords: ICT literacy, information literacy, university libraries, computer literacy,

\title{
Introduction
}

Libraries all over the world are applying information and communication technologies (ICT) to their operations. University libraries have been in the forefront of ICT application to library services. The uses of these technologies require training and re-training of staff which brings about information and communication technology literacy. According to King (2007), ICT literacy is the ability to use digital technologies, communication tools and or networks to solve information problems in order to function in the information society. Rockman (2005) also defined ICT literacy as the ability to know what resources are available, what information is within these sources and how to use technology to access and communicate information. The term ICT literacy has been used severally to mean the same as information literacy (IL) and computer literacy (CL) but they are not the same. Amalahu, Oluwasina and Laoye (2009) stated that Information literacy includes library literacy, media literacy, computer literacy, research literacy, and critical thinking skills. Everhart and Valenza (2004) differentiated between the two terms thus; Information literacy is a broader concept because information technology supports information literacy. They stressed further that an information literate (IL) person will be able to employ computer and information technology to access, retrieve, store, manage and communicate information. Computer literacy can be defined as the understanding of what computer hardware and software can do. It is the competence to use computers to complete a task. Although computer literacy plays an important role in accessing information, information literacy goes beyond computer literacy. A closely related concept is information fluency. According to Sharkey (2006) information fluency is the integration of information literacy, critical thinking and the ability to use technology to find information. Rader (2004) defined 
information fluency as the ability to navigate information structures and to evaluate information retrieved through these structures. Harris and Millet (2006) came to the conclusion that information fluency is the fusion of literacies and that it is the optimal outcome when critical thinking skills are combined with information, computer and information communication technology literacy.

To enhance job performance and keep abreast with trends in the library profession, the library staff in Nigerian universities are required to know the basic computer operations such as turning the computer on, opening a folder, copying a file from one disk to another, scanning etc. In addition to these basic operations, library staff should also be familiar with the use of application software such as creating a new word processor document, modifying an existing word processor document, print out a document, operating in a networked environment such as local area network (LAN) and wide area network (WAN). Furthermore, library staff especially in this digital era is expected to exhibit some degree of expertise in various aspects of library and information work. Skills such as using the Internet for research, sending e-mails, find specific information, taking part in an online discussion or chatting (videoconferencing), and sending /attaching file to an e-mail, using a www search engine such as yahoo, google, MSN etc, using keywords or phrases to search for information on the www etc. These skills when acquired will improve enhance the performance of library staff.

ICTs are widely acknowledged as important resources for advancement in libraries all over the world particularly in this information age. Various technologies have emerged in libraries and more are still emerging. Due to these developments, many university libraries in Nigeria are applying ICTs to their operations and services to keep abreast with trends and to meet users' information needs. There is no gain saying that Nigeria Library Association has been instrumental to this feat through its Conferences and Annual General Meetings which have been motivating to embrace the new information age. However, this development is not without challenges as it involves a new way of doing old things. New skills are required to carry out existing roles and functions. Going by the various ICT campaigns and initiatives in the Nigeria university libraries to promote and improve on ICT literacy, coupled with the numerous ICT literacy opportunities available for the staff in Nigerian University libraries, and the capital invested in ICTs by University libraries in Nigeria, it is observed that most of the routine jobs are still carried out manually in the libraries. One would expect that after training and retraining in the area of ICTs, library staff should be competent in using ICTs to perform their duties. Studies (Adeyoyin, 2005, Ugboma ,2006, Ugwuanyi,2009, Ngorgo,2012, Oguche 2014, Nkamnebe etal., 2015) have shown that there is still a gap between literacy and competence among staff in Nigerian Federal University libraries which calls for attention. It is against this backdrop, that this study is embarked upon to assess the ICT literacy competence of library staff in Nigerian Federal Universities.

\section{Objective of the study}


The objective of the study is to determine the:

1) ICT literacy competence of library staff in Nigerian federal University libraries

2) Impact of ICT literacy competence on the duties of the library staff in Nigerian federal university libraries

\section{Research questions}

In order to carry out the research, the following research questions were posed:

1) What is the ICT literacy competence of library staff in Nigerian federal University libraries?

2) What is the impact of ICT literacy competence on the duties of the library staff in Nigerian federal university libraries?

\section{Hypothesis}

The following research hypothesis was tested:

1) There is no significant difference in the levels of ICT literacy competence among the library staff in the Nigerian Federal university libraries studied.

\section{Literature Review}

Today libraries are changing the way they deliver information services to users due to the dynamism of Technology. Consequently, information professionals are acquiring new skills in order to keep abreast with the trend and these skills are regarded as Information and Communication Technology (ICT) skills. According to Authur and Hart (1990), personal characteristics such as low cognitive skill can influence the ICT literacy level of an individual. This view is realistic because a library staff with low cognitive ability level may lack the opportunity to develop computer or ICT skills, or consciously opt not to become familiar with computers due to the perceived difficulty in learning about, and using, computer technology. Newman (1997) submitted that education, gender difference, income, age and availability of ICT facilities are factors that can influence ICT literacy level. In addition, Nakhaie (1998) noted that male individuals tend to have more positive attitudes toward computers regardless of their level of familiarity while the female attitude becomes more positive as their level of familiarity with computers increases.

Similarly, Linden and Adams (2009) observed that age differences regarding ICT use and skills may influence ICT literacy level and young people are more likely to be ICT users and more ICT literate than older age groups because older individuals are slower to respond to rapid change in technology and increased reliance on computers than younger individuals. However, with adequate training, older individuals can adapt to new information technologies. The above opinion may be attributed to youthful exorbitance and passion for new discovery on the part of the young people. The older people may already have enough to contend with, have little or no 
time to follow trends in technology.

As noted by Menou (2002), the potentials of the information age cannot be realized without expanding the scope of information and computer literacy. This can be achieved by retooling the information professionals and sensitizing them to be able to use stand-alone computers, computer networks (primarily the Internet), basic application software such as word processing, spread sheet, electronic mail and possibly more advanced ones such as presentations, production of web pages, construction of websites, use of digital multimedia equipment and programmes. In the same vein, librarians in Nigerian federal university libraries would have to be retooled with ICT literacy and sensitized on the benefits of such literacy on their job performance.

In a survey of eighteen Nigerian university libraries by Adedoyin (2005), it was discovered that a gap existed between desired levels of ICT literacy and the actual levels of literacy of the surveyed librarians. This may be due to some of the factors mentioned earlier above such as gender and age. Similarly, a study on the ICT literacy among practicing librarians in Delta state, Nigeria by Ugboma (2006) revealed that even though the practicing librarians in that region were more familiar with and constantly use ICT models of mobile telephony, electronic mails, fax etc., they were yet to be fully ICT literate. This brings to mind the question of what should be regarded as full ICT literacy. The findings above both suggest that the librarians were familiar with computers but not proficient in the use of the available ICT infrastructure in their libraries. If they were ICT literates, perhaps gaps would not have existed. Another study on the ICT literacy among academic librarians in Enugu state, Nigeria by Ugwuanyi (2009) revealed that the level of ICT literacy skills among the librarians in Enugu state is low due to non-availability of ICT infrastructure in most of the tertiary institutions thereby hindering effective acquisition of ICT literacy skills. It also revealed that librarians were interested to adopt the current trend of ICT literacy and application in the present day ICT environment but were incapacitated by limited self-effort and library management policy decisions. Other factors which contributed to the low level of ICT literacy among the librarians in the study were poor finance, conservatism and limited opportunities.

\section{Methodology}

Survey research method was used to ascertain the opinion of the respondents. The population of the study consisted of six (6) selected Nigerian Federal University Libraries one each from the six geo-political zones namely; Kashim Ibrahim Library, A.B.U, Zaria (NorthWest), University of Ilorin Library (North-Central), Ramat library, University of Maiduguri (North-East), University of Nigeria, Nsukka library (South-East), University of Calabar library, (South-South) Kenneth Dike Library University of Ibadan (South-West) respectively. The subjects however, comprised of three hundred and sixty four (364) library staff from the selected university libraries. Questionnaire and oral interview were instruments used for data collection. Frequency distribution tables, simple percentages and charts were used to present the data 
collected while the Chi square test was used to test the hypothesis.

\section{Findings and discussion}

Out of the 364 copies of the questionnaire distributed to the library staff, a total of $290(79.7 \%)$ copies were returned duly completed and found usable for this study.as indicated on table 1 below:

Table 1: Response Rate of the Library Staff according to their Universities

\begin{tabular}{|l|c|c|c|}
\hline University Libraries & $\begin{array}{l}\text { No. of } \\
\text { Questionnaires } \\
\text { Distributed }\end{array}$ & $\begin{array}{l}\text { No. of } \\
\text { Questionnaires } \\
\text { Returned }\end{array}$ & $\begin{array}{l}\text { Percentage of } \\
\text { Questionnaires } \\
\text { Returned }\end{array}$ \\
\hline $\begin{array}{l}\text { Ramat Library, University of } \\
\text { Maiduguri }\end{array}$ & 26 & 24 & $6.6 \%$ \\
\hline $\begin{array}{l}\text { Kashim Ibrahim Library (KIL) } \\
\text { A.B.U Zaria }\end{array}$ & 110 & 78 & $21.4 \%$ \\
\hline $\begin{array}{l}\text { Kenneth Dike Library, University } \\
\text { of Ibadan }\end{array}$ & 73 & 60 & $16.5 \%$ \\
\hline $\begin{array}{l}\text { University of Calabar Library, } \\
\text { Calabar }\end{array}$ & 60 & 48 & $13.2 \%$ \\
\hline $\begin{array}{l}\text { University of Ilorin Library, Ilorin } \\
\text { Total }\end{array}$ & 43 & 41 & $10.7 \%$ \\
\hline $\begin{array}{l}\text { University of Nigeria Library, } \\
\text { Nsukka }\end{array}$ & $\mathbf{3 6 4}$ & $\mathbf{2 9 0}$ & $11.3 \%$ \\
\hline
\end{tabular}

\section{Research question 1:}

What is the ICT literacy competence of library staff in Nigerian federal University libraries?

In order to achieve this, a list of ICT literacy competences were provided for the respondents to make a self-assessment of their competences using a harmonized Likert scale of Competent (CT), Undecided (UD) and Not Competent (NC) respectively. Below is table 2 indicating their responses: 
Table 2: ICT Literacy Competence of library staff in Nigerian Federal University Libraries

\begin{tabular}{|c|c|c|c|c|c|c|c|}
\hline \multirow{3}{*}{ ICT LITERACY } & \multicolumn{6}{|c|}{ Level of Competence } & \multirow{3}{*}{$\begin{array}{c}\text { Weighte } \\
\text { d } \\
\text { Average }\end{array}$} \\
\hline & \multicolumn{2}{|c|}{ Competent } & \multicolumn{2}{|c|}{ Undecided } & \multicolumn{2}{|c|}{ Not Competent } & \\
\hline & $\mathbf{F}$ & $\%$ & $\mathbf{F}$ & $\%$ & $\mathbf{F}$ & $\%$ & \\
\hline Turning a computer on and off & 168 & 58.0 & 68 & 23.4 & 54 & 18.6 & 127.0 \\
\hline Opening a computer file & 128 & 44.1 & 92 & 31.7 & 70 & 24.1 & 109.0 \\
\hline Backing-up a computer file & 118 & 40.7 & 98 & 33.8 & 74 & 25.5 & 104.5 \\
\hline Deleting a computer file & 128 & 44.1 & 89 & 27.9 & 73 & 25.1 & 109.4 \\
\hline Creating a directory or folder & 126 & 43.5 & 84 & 28.9 & 80 & 27.6 & 109.3 \\
\hline $\begin{array}{l}\text { Copying a file from one disk to } \\
\text { another }\end{array}$ & 94 & 32.4 & 61 & 21.0 & 135 & 46.6 & 100.1 \\
\hline $\begin{array}{l}\text { Connecting to the Internet from } \\
\text { a remote computer }\end{array}$ & 166 & 57.2 & 59 & 20.3 & 65 & 22.4 & 127.4 \\
\hline Installing software on a computer & 126 & 43.4 & 101 & 34.8 & 63 & 21.7 & 107.1 \\
\hline Ms Word Application & 173 & 59.7 & 54 & 18.6 & 63 & 21.7 & 130.6 \\
\hline Ms Excel Application & 95 & 32.8 & 91 & 31.4 & 104 & 35.9 & 96.8 \\
\hline Ms Access Application & 90 & 31.0 & 95 & 32.8 & 105 & 36.2 & 94.4 \\
\hline Ms Power Point & 169 & 58.3 & 66 & 22.8 & 55 & 18.9 & 127.6 \\
\hline Library Application Software & 121 & 41.7 & 99 & 33.8 & 70 & 24.1 & 105.5 \\
\hline Navigating the world wide web & 117 & 40.3 & 92 & 31.7 & 81 & 27.9 & 104.9 \\
\hline Sending an email message & 168 & 58.0 & 52 & 18.6 & 70 & 24.1 & 129.0 \\
\hline $\begin{array}{l}\text { Using the www to find specific } \\
\text { Information }\end{array}$ & 114 & 39.3 & 104 & 35.9 & 72 & 24.8 & 102.3 \\
\hline $\begin{array}{l}\text { Taking part in an online } \\
\text { discussion or chat }\end{array}$ & 126 & 43.5 & 54 & 17.9 & 110 & 37.9 & 113.0 \\
\hline $\begin{array}{l}\text { Sending an attachment with an e- } \\
\text { mail message }\end{array}$ & 119 & 41.0 & 97 & 33.5 & 74 & 25.5 & 105.0 \\
\hline Downloading files from the internet & 115 & 39.7 & 71 & 24.5 & 104 & 35.9 & 106.8 \\
\hline $\begin{array}{l}\text { Saving an image or graphic from } \\
\text { a www page }\end{array}$ & 70 & 24.1 & 93 & 32.1 & 127 & 43.8 & 87.1 \\
\hline Using search engine e.g. Google & 169 & 58.3 & 80 & 27.6 & 41 & 14.1 & 125.9 \\
\hline $\begin{array}{l}\text { Using keywords phrases to search } \\
\text { for information on the www }\end{array}$ & 71 & 24.5 & 118 & 40.7 & 101 & 34.8 & 84.4 \\
\hline $\begin{array}{l}\text { Using advanced searching } \\
\text { techniques }\end{array}$ & 85 & 29.3 & 59 & 20.3 & 146 & 50.3 & 97.0 \\
\hline Searching online databases & 123 & 42.4 & 68 & 23.5 & 99 & 34.1 & 110.1 \\
\hline OPAC & 163 & 56.2 & 57 & 19.7 & 70 & 24.1 & 126.5 \\
\hline
\end{tabular}


Table 2 ,above indicates that over $50 \%$ of the library staff studied were competent in using search engines, the use of Microsoft application software such as Ms Word and Ms Power Point, sending an e-mail message and the use of OPAC respectively while those who were competent in the other ICT literacy skills ranged from $24 \%$ to $45 \%$. This may be attributed to the availability of personal computers and internet facilities in all the university libraries studied. Unfortunately, between $14 \%$ and $43 \%$ of the respondents were not competent in the outlined competencies. These may be attributed to lack of personal effort on the part of the respondents.

$17.9 \%$ to $35 \%$ of the respondents were undecided on their ICT literacy competences.

The weighted average ranks Ms Word, Sending email message, Ms Power Point, connecting to the internet and use of OPAC as the items with highest competences. The implication of this finding is that Nigeria University libraries are bridging the digital divide especially with respect to ICTs availability and usage. Activities like acquisition, cataloguing, circulation control, serials control etc, which were carried out manually in libraries with so much of strain are gradually fading away. This suggests that the library staff in the university libraries studied may be performing their jobs with greater efficiency using the ICTs. The finding is line with Aina (2004) who noted that ICT is tremendously changing the management of resources or housekeeping operations as well as the way services are delivered in the Nigerian university libraries.

\section{Research question 2:}

What is the impact of ICT literacy competence on the duties of the library staff in Nigerian federal university libraries?

To achieve this, a list of hypothetical statements was provided for the library staff to indicate their opinion. Below is table 3 showing the opinion of the library staff:

Table 3: Opinion of library staff on the extent of the impact of ICT literacy competence on their duties

\begin{tabular}{|c|c|c|c|c|c|c|c|}
\hline \multirow{3}{*}{$\begin{array}{l}\text { Effect of ICT literacy } \\
\text { on job performance }\end{array}$} & \multicolumn{6}{|c|}{ Opinion of library staff } & \multirow{3}{*}{$\begin{array}{c}\text { Weighted } \\
\text { Average }\end{array}$} \\
\hline & \multicolumn{2}{|c|}{ Agreed } & \multicolumn{2}{|c|}{ Undecided } & \multicolumn{2}{|c|}{ Disagreed } & \\
\hline & $\mathbf{F}$ & $\%$ & $\mathbf{F}$ & $\%$ & $\mathbf{F}$ & $\%$ & \\
\hline $\begin{array}{l}\text { It has simplified my work } \\
\text { process }\end{array}$ & 189 & 65.2 & 76 & 26.2 & 25 & 8.6 & 133.9 \\
\hline $\begin{array}{l}\text { It has helped me to } \\
\text { always complete my } \\
\text { tasks }\end{array}$ & 96 & 33.1 & 108 & 37.2 & 86 & 29.7 & 95.0 \\
\hline
\end{tabular}




\begin{tabular}{|l|c|c|c|c|c|c|c|}
\hline $\begin{array}{l}\text { It has improved my } \\
\text { ability perform } \\
\text { to }\end{array}$ & 145 & 50.0 & 65 & 22.4 & 80 & 27.6 & 118.8 \\
\hline $\begin{array}{l}\text { It has motivated me to do } \\
\text { my job }\end{array}$ & 159 & 54.8 & 72 & 24.8 & 59 & 20.4 & 123.1 \\
\hline $\begin{array}{l}\text { It has increased my } \\
\text { aptitude }\end{array}$ & 105 & 36.2 & 87 & 30.0 & 98 & 33.8 & 101.0 \\
\hline $\begin{array}{l}\text { It has impelled my desire } \\
\text { to work }\end{array}$ & 147 & 50.7 & 70 & 24.1 & 73 & 25.2 & 118.9 \\
\hline $\begin{array}{l}\text { It has prompted my } \\
\text { commitment to job }\end{array}$ & 73 & 25.1 & 128 & 44.1 & 89 & 30.8 & 83.9 \\
\hline
\end{tabular}

Table 3 revealed that $65 \%$ of the respondents agreed to the opinion that ICT literacy has helped them to simplify their work process. Unfortunately $9 \%$ disagreed with this opinion. The interview session with the library staff revealed that while they agreed to the opinion that their ICT literary competence has simplified their work process, they noted that their work volume had also increased. When asked if ICT literacy has prompted their commitment to job, $25 \%$ agreed while $31 \%$ disagreed. The fact that as much as $44 \%$ of the respondents were undecided suggested that the respondents may not have been convinced of their commitment to the job.

The implication of this finding is that Nigeria University libraries have realized that staff performance depends among other things, their ability and motivation. The staff will perform their jobs better when they are committed and given the required training. Khan (2009) posited that performance is the product of ability multiplied by motivation; ability is the product of aptitude multiplied by training and resources; while motivation is the product of desire multiplied by commitment

It can therefore be inferred that, Nigeria university libraries should keep the two variables of ability and motivation at equilibrium for their staff to perform well on the job. This is because; a library staff with $100 \%$ motivation and $75 \%$ ability can perform library duties at above-average rate. However, if the individual has only $10 \%$ of the ability required, no amount of motivation will make him or her to perform his duty satisfactorily.

\section{Hypotheses}

Ho:

There is no significant difference in the levels of ICT literacy competence among the library staff in the Nigerian federal university libraries studied 
Table 4: Analysis of Variance on the ICT literacy competence of the library staff in the Federal university libraries studied

\begin{tabular}{|l|c|l|l|l|l|l|}
\hline Source of variance & $\begin{array}{c}\text { Sum of } \\
\text { Squares }\end{array}$ & \multicolumn{1}{|c|}{ DF } & $\begin{array}{c}\text { Means of } \\
\text { Squares }\end{array}$ & F & P & F critical \\
\hline Between Groups & 5166.200 & 5 & 1033.240 & 122.491 & .000 & 2.44 \\
Within Groups & 354.279 & 42 & 8.435 & & & \\
\hline Total & 5520.479 & 47 & & & \\
\hline
\end{tabular}

Table 4 above shows the analysis of variance on the ICT literacy competence of the library staff in the federal university libraries studied at $\mathrm{P}<0.05$ level of significance. The $\mathrm{F}$ calculated 122.491 is greater than the F critical 2.44. The null hypothesis $\left(H_{0}\right)$ is therefore rejected. This implies that among the federal university library staff studied, some were found more competent in the use of ICTs than others. The table 4.1 below shows the result of the Post hoc multiple comparisons on the mean scores of the different university libraries studied.

Table 4.1: A Post hoc Scheffe Test of multiple comparisons on the ICT literacy competence of the library staff in the Federal university libraries studied.

\begin{tabular}{|c|c|c|c|c|c|}
\hline $\begin{array}{c}\text { Dependent } \\
\text { Variable }\end{array}$ & $\begin{array}{l}\text { (i) University } \\
\text { Libraries }\end{array}$ & $\begin{array}{l}\text { (j) University } \\
\text { Libraries }\end{array}$ & $\begin{array}{c}\text { Mean } \\
\text { Difference } \\
(\mathbf{I}-\mathbf{J})\end{array}$ & $\begin{array}{c}\text { Standard } \\
\text { Error }\end{array}$ & Significance \\
\hline \multirow{15}{*}{$\begin{array}{l}\text { ICT Literacy } \\
\text { Competence }\end{array}$} & \multirow[t]{5}{*}{$\mathrm{RL}$} & KIL & $-32.94444(*)$ & 1.53072 & .000 \\
\hline & & KDL & $-20.91667(*)$ & 1.56853 & .000 \\
\hline & & UCL & $-12.50000(*)$ & 1.67682 & .000 \\
\hline & & UIL & $-9.43939(*)$ & 1.47401 & .000 \\
\hline & & UNNL & $-9.29167(*)$ & 1.56853 & .000 \\
\hline & \multirow[t]{5}{*}{ KIL } & $\mathrm{RL}$ & $32.94444(*)$ & 1.53072 & .000 \\
\hline & & KDL & $12.02778(*)$ & 1.41126 & .000 \\
\hline & & UCL & $20.44444(*)$ & 1.53072 & .000 \\
\hline & & UIL & $23.50505(*)$ & 1.30541 & .000 \\
\hline & & UNNL & $23.65278(*)$ & 1.41126 & .000 \\
\hline & \multirow[t]{5}{*}{ KDL } & RL & $20.91667(*)$ & 1.56853 & .000 \\
\hline & & KIL & $-12.02778(*)$ & 1.41126 & .000 \\
\hline & & UCL & $8.41667(*)$ & 1.56853 & .000 \\
\hline & & UIL & $11.47727(*)$ & 1.34953 & .000 \\
\hline & & UNNL & $11.62500(*)$ & 1.45217 & .000 \\
\hline
\end{tabular}




\begin{tabular}{|l|l|l|c|l|r|}
\hline & UCL & RL & $12.50000\left(^{*}\right)$ & 1.67682 & .000 \\
& KIL & $-20.44444\left(^{*}\right)$ & 1.53072 & .000 \\
& & KDL & $-8.41667\left(^{*}\right)$ & 1.56853 & .000 \\
& UIL & 3.06061 & 1.47401 & .514 \\
& UNNL & 3.20833 & 1.56853 & .531 \\
\cline { 3 - 5 } & UIL & RL & $9.43939\left(^{*}\right)$ & 1.47401 & .000 \\
& KIL & $-23.50505\left(^{*}\right)$ & 1.30541 & .000 \\
& KDL & $-11.47727\left(^{*}\right)$ & 1.34953 & .000 \\
& UCL & -3.06061 & 1.47401 & .514 \\
& UNNL & .14773 & 1.34953 & 1.000 \\
\cline { 3 - 5 } & UNNL & RL & $9.29167\left(^{*}\right)$ & 1.56853 & .000 \\
& KIL & $-23.65278(*)$ & 1.41126 & .000 \\
& KDL & $-11.62500\left(^{*}\right)$ & 1.45217 & .000 \\
& UCL & -3.20833 & 1.56853 & .531 \\
& UIL & -.14773 & 1.34953 & 1.000 \\
\hline
\end{tabular}

* indicates that the mean difference is significant at 0.05level

Key:

RL: Ramat Library

KIL: Kashim Ibrahim Library

KDL: Kenneth Dike Library

UCL: University of Calabar Library

UIL: University of Ilorin Library

UNNL: University of Nsukka, Nigeria Library

From the results of the analysis, the following findings were made;

1. The staff in all the federal university libraries studied were competent in sending emails, use of search engines, the use of Microsoft application software such as Ms Word and Ms Power Point, connecting to the internet and the use of OPAC

2. The ICT literacy competence of library staff in all the federal university libraries studied has helped them to simplify their work process and also motivated them to do their jobs.

3. the ICT literacy competence of library staff in Nigerian federal university libraries has significant impact on their duties

\section{Conclusion and Recommendations}

The analysis and discussion of the findings clearly indicates that the impact of ICT literacy competence on the duties of library staff in the Nigerian federal university libraries studied is on the average. The influx of smart phones and other mobile device technologies such as iPad and tablets may have also impacted the ICT literacy of the library staff. However, the level of their ICT competence can be improved upon if necessary measures such as regular ICT capacity building among others are taken. This will no doubt reduce rather than widen the digital divide 
between the developed and the developing countries which Nigeria is one.

Based on the findings from this study, the following are recommended;

1. Library and Information Science schools in Nigerian Universities should introduce ICT literacy as a full fledge credit course in all levels of their curriculum/programs and make it a core course. This will go a long way to equip prospective librarians with requisite ICT skills before employment and also make them competent in the use of ICTs.

2. Nigerian university libraries should collaborate, seek and scout for ICT literacy training assistance from foreign bodies (government, foundations, corporations etc.) such as Melinda and Gates foundation USA, UNESCO, UN, EEU etc.

3. As a strategy, the Nigerian federal university libraries should formulate and implement policies that will ensure staff ICT development in at least every 18 months. This will keep the library staff abreast with current trends and developments in ICT especially as it relates to the library profession.

4. The federal university libraries should also develop motivational strategies such as ICT scholarship award/grants to staff who distinguished themselves particularly in library related areas of ICT to encourage them to be responsive to ICT literacy.

\section{References}

Adedoyin, S. (2005), Information and Communication Technology Literacy (ICT) among the staff of Nigerian University Libraries. Library Review, Vol.54 No.4, pp. 257 - 266.

Amalahu, C. Oluwasina, O. and Laoye, O. (2009). Higher Education and Information Literacy: A Case Study of Tai Solarin University of Education. Library Philosophy and Practice. Retrieved from http://unllib.unl.edu/LPP/amalahu-oluwasina-laoye.pdf

Arthur, W. and Hart, D. (1990), "Empirical relationship between cognitive ability and computer familiarity". Journal of Research on Computing in Education, Vol. 21, pp. 457463.

Everhart, N. and Valenza, J. (2004). Internet - savvy students and their schools. Knowledge Quest, 32 (4): 50 - 54.

Harris, B. and Millet, M. (2006). Nothing to lose: "fluency" in information literacy theory and practice. Reference services review, 34 (4): 520 - 535.

Ferrigan, C. (2007), Passing the ICT skills Test, Learning Matters Ltd, London.

Khan, B. Khan M. and Khan A. (2009), "Motivation and its impact on job performance", Retrieved from http://www.motivation.htm

King, L. (2007). Information literacy of incoming Undergraduate Arts Students of University of Western Cape: assessment of competencies and proficiencies. A thesis submitted in partial fulfillment of the requirements for the degree of Philosophy Doctor in the Department of Library and Information Science, University of the Western Cape, South-Africa

Linden, R. and Adams, S. (2009). Technological change: its effects on the training and performance of older employees, in Gomez-Mejia, L. and Lawless, M. (Eds.), Advances in Global High-Technology Management, JAI Press, Greenwich 
Maldeni, H. and Jayasena, S. (2009). Information and Communication Technology Usage and Bank Branch Performance, The International Journal on Advances in ICT for Emerging Regions, Vol.2 No.2, pp. 29 - 37

Menou, M. (2002).Information Literacy in National Information and Communication Technology (ICT) policies: The missed Dimension, Information culture", White paper prepared for UNESCO, the U.S. National Commission on Libraries and information Science, and the National Forum on Information Literacy, for use at the Information Literacy Meeting of Experts, Prague, The Czech Republic.

Murray, J. (2005. Testing Information literacy skills (grades k-12): information skills for student achievement. Retrieved from http://www.big6.com/showarticle.php

Nakhaie, M. (1998). Social origins, social statuses and home computer access and use. Canadian Journal of Sociology, vol. 23, pp. 427-450

Newman, L. Cooper, J. and Ruble, D. (1995). Gender and computers II: the interactive effects of knowledge and constancy on gender-stereotyped children, Sex Roles, Vol. 33, pp. 325-351.

Ngorgor, R. (2012). Information and Communications Technology Literacy skill level of staff of National Library of Nigeria. Unpublished MLS Thesis, Dept of Library and Information Science, University of Nigeria, Nsukka.

Nkamnebe, E., Okeke, I., Udem, O. and Nkamnebe, C. (2015). Extent of Information and Communication Technology skills Possessed by librarians in University libraries in Anambra state, Nigeria. Information and Knowledge Management, Vol.5 No.9, pp. 22-31

Oguche, D. (2014). Effect of Information and Communication Technologies Literacy Competence on Job Performance of Library Staff in Nigerian Federal University Libraries. Unpublished MLS Thesis, Dept of Library and Information Science, Ahmadu Bello University, Zaria.

Oliver, R. and Towers, S. (2000). Benchmarking ICT Literacy in Tertiary Learning Settings. Retrieved from http://www.ascilite.org.au/conferences/coffs00/papers/ron_Oliver.pdf

Rader, H. (2004). Building faculty-librarian partnerships to prepare students for information fluency: the time for sharing information expertise is now. College and research libraries news, 65 (2): $74-90$.

Rockman, F. (2005). ICT literacy. Reference and service review, 33 (2): 141 - 143.

Schuler, J. (2009). Measuring the impact of ICT literacy: Library perspective. Retrieved from http://works.bepress.com/john_ainely/12 (accessed 10 July 2016)

Sharkey, J. (2006). Towards information fluency: applying a different model to an information literacy credit course. Reference services review, 34 (1): 71 - 85.

Ugboma, M. (2006), "Information and Communication Technology Literacy among Practicing Librarians in Delta State”, The Information Manager, Vol.6 No.1\&2, pp. 12-26

Ugwuanyi, C. (2009). Information and Communication Technology (ICT) literacy among Academic Librarians in Enugu State, International Journal of Information and Communication Technology, Vol.6 No.1, pp. 123 - 132

Umar, L. (2010). Application of customer relationship management in information service 
delivery in university libraries in north western states of Nigeria, Unpublished MLS Thesis, Dept of Library and Information Science, Ahmadu Bello University, Zaria.

Wijaya, S. and Sunrendro, K. (2007), "ICT literacy as an indicator of e-government Readiness", Retrieved from: http://www.usd.ac.ld/06/publidosen/wisnu-ti/ict.pdf

Zammit, L. (2008). ICT Literacy and Education in Malta,Retrieved at http://www.mirac.edu/literacy/education/zam.pdf

David Oguche is with the Nigerian Institute of Advanced Legal Studies, Supreme Court Complex 3 Arms Zone, FCT - ABUJA, Nigeria. He can be reached at ogucheed@yahoo.com 